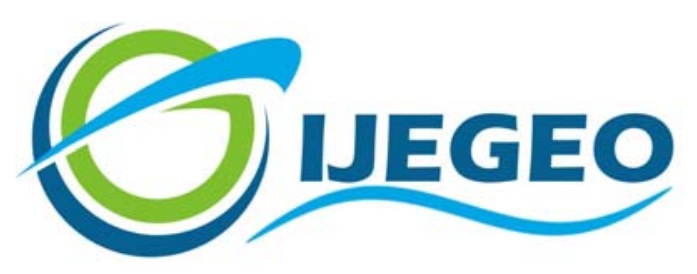

International Journal of Environment and Geoinformatics (IJEGEO) is an international, multidisciplinary, peer reviewed and certified open access journal.

\title{
Analysis of flood susceptibility and zonation for risk management using frequency ratio model in District Charsadda, Pakistan
}

\section{Muhammad Farhan UI Moazzam, Anujit Vansarochana and Atta-Ur-Rahman} Editors

\author{
Prof. Dr. Cem Gazioğlu, Prof. Dr. Dursun Zafer Şeker, Prof. Dr. Ayşegül Tanık,
}

Prof. Dr. Şinasi Kaya, Assist. Prof. Dr. Volkan Demir

\section{Scientific Committee (2018)}

Dr. Abdullah Aksu, Prof. Dr. Bedri Alpar, Prof. Dr. Gülşen Altuğ, Prof. Dr. Lale Balas, Prof. Dr. Can Balas, Prof. Dr. Levent Bat, Prof. Dr. Bülent Bayram, Prof. Dr. Nuray Çağlar, Prof. Dr. Jadunandan Dash, Prof. Dr. A. Evren Erginal, Dr. Dieter Fritsch, Dr. Amin Gharehbaghi, Assoc. Prof. Dr. Tolga Görüm, Prof. Dr. Melike Gürel, Dr. Hakan Kaya, Prof. Dr. Fatmagül Kılıç, Assoc. Prof. Dr. Maged Marghany, Prof. Dr. Nebiye Musaoğlu, Prof. Dr. Masafumi Nakagawa, Prof. Dr. Haluk Özener, Prof. Dr. Erol Sarı, Prof. Dr. Elif Sertel, Prof. Dr. Nüket Sivri, Assoc. Prof. Dr. Füsun Balık Şanlı, Prof. Dr. Uğur Şanlı, Assoc. Prof. Dr. Hasan Özdemir, Prof. Dr. Taşkın Kavzoğlu, Msc. Mustafa Üstüner, Assoc. Prof. Dr. Oral Yağcı, Prof. Dr. Seyfettin Taş, Assoc. Prof. Dr. Ömer Suat Taşkın, Assoc. Prof. Dr. İ. Noyan Yılmaz, Dr. Baki Yokeş, Dr. Sibel Zeki 


\title{
Analysis of flood susceptibility and zonation for risk management using frequency ratio model in District Charsadda, Pakistan
}

\author{
Muhammad Farhan Ul Moazzam $^{1 *}$, Anujit Vansarochana ${ }^{1}$, Atta-Ur-Rahman ${ }^{2}$ \\ ${ }^{1}$ Department of natural resources and environment, Faculty of Agriculture, Natural resources and environment, \\ Naresuan University, 65000, Thailand. \\ ${ }^{2}$ Department of Geography, University of Peshawar, Peshawar 25120, Pakistan \\ Corresponding author* \\ $\begin{array}{llllll}\text { Tel } & :+66954825725 & \text { Received } & 17 & \text { March } & 2018\end{array}$ \\ E-mail :farhan.moazzam@gmail.com $\quad$ Accepted $05 \quad$ July 2018
}

\begin{abstract}
This study focuses on the analysis of flood susceptibility and resultant zonation for risk management using frequency ratio model in District Charsadda, Pakistan. To achieve the study objectives, a reconnaissance survey was conducted, and frequent flood inundated areas were identified in the study area by interpretation of Landsat 7 image together with the intensive field survey, a total of 161 flooded locations were demarcated at different part of the district with handheld GPS. As a result, an inventory of spatial database of past flood inundation was generated and role of all the influencing factors for detecting the extent of flood susceptibility. During flood susceptibility analysis, ten conditioning parameters including: elevation, slope, aspect, curvature, plan curvature, profile curvature, proximity to roads, proximity to streams, proximity to river and land use/land cover were selected. A correlation between conditioning factors and flood was calculated using frequency ratio method. Consequently, the summation of frequency ratio values was taken for all the parameters for development of flood susceptibility index. The flood susceptibility index was then classified into five zones of very low (27.64\%), low (39.88\%), moderately susceptible $(22.25 \%)$, high susceptible $(7.78 \%)$, very high $(2.46 \%)$. So, for the likelihood of the model was determined using success rate curve method, area under curve acquired for the model was 0.9226 . The flood susceptibility zones could be used for flood risk management and land use planning for minimizing the potential risk in the floodplain of rivers flowing through the study area.
\end{abstract}

Keywords: Flood locations, FR method, Flood density, Hazard mitigation

\section{Introduction}

Floods are the most common and destructive natural disaster which has the effect on a very large area (Dilley, 2005).It is estimated that $1 / 3$ of the world's land is prone to flood which affect $82 \%$ of population. More than 90 countries in the world are vulnerable to disastrous flood and world widely more than 170,000 people died due to recurrent floods from 1980-2000 (UNDP, 2004). These figures are alarming and evident that flood is a global problem and need proper flood management. Prolonged heavy rainfall, melting of snow, climate change, blockage of drainages, and population increase especially in urban areas are the major triggering factors of flood disaster (Adeoye et al., 2009). In
Pakistan monsoon rainfall is major cause of summer floods occur; in addition, the historical 2010's flood in Pakistan was the most terrible in sense of intense and prolonged rainfall, heavy flood discharge, and extent of affected people and their damaged properties (Atta-ur-Rahman and Khan, 2013). Abnormal rainfall was recorded by almost all the metrological stations in the country and the main cause behind this disastrous flooding was the consecutive rainfall for four days (27-30 July) (A. N. Khan et al., 2013). Khyber Pakhtunkhwa province was the worst affected in 2010 flood. District Charsadda is one of the Districts in province of Khyber Pakhtunkhwa which is prone to riverine and flashflood due to the banks of Kabul and Swat river. Around 
200-280 mm rainfall was recorded in District Charsadda, Peshawar, and Nowshera. As a result River Swat and River Kabul were remained in high to very high flood stage $(300,000$ Cusec) and $(221,000$ Cusec $)$ respectively (Ahmad et al., 2011; Brivio et al., 2002; A. N. Khan et al., 2013). Flashflood in District is associated with the capability of rivers due to that flood occurs within few hours of heavy rainfall (A. N. Khan et al., 2013). So, it is necessary to have flood susceptibility map for the prone areas. GIS techniques used to map the flooded area and reduce the flood damages in future (Duan et al., 2009). These maps can be used for flood monitoring, emergency management and rapid response (Azaz, 2010). In 20th century GIS is getting advance very rapidly so, one can use GIS techniques to assess the flood damaged areas (Uddin and Shrestha, 2011). Remote sensing techniques are actively participating to identify the locations of flooded areas, Landsat 7 image used and flood location were demarcated in the study area (Uddin et al., 2013; Uddin and Shrestha, 2011). Flood and the associated damages can be monitor by remotely sensed images for emergency response and relief work (Forkuo, 2008). The range and application of geoinformatics has been increased due to its capability to integrate the spatio-statistical techniques and has potential to handle large datasets. In this study GIS based frequency ratio method has been used which is an empirical quantitative approach, which provide the relationship between flood locations and its triggering factors (M. J. Lee et al., 2012; S. Lee and Pradhan, 2007; Algan et al., 1999; Kaya and Gazioğlu, 2015; Rahmati et al., 2016; Yalcin et al., 2011).

District Charsadda stretches between $34^{\circ} 2^{\prime} 42^{\prime \prime}$ to $34^{\circ} 27^{\prime} 24^{\prime \prime}$ North Latitude and 71 $29^{\prime} 10^{\prime \prime}$ to $71^{\circ} 56^{\prime} 7^{\prime \prime}$ East Longitude (Fig. 1). District Charsadda is located at a distance of $30 \mathrm{Km}$ from provincial capital Peshawar. Total area of the District is $996 \mathrm{Km} 2$. According to the 2017 census population, the District population is 1,616,198 (PBS, 2017). District is divided into three tehsils i.e. Charsadda, Tangi, and Shabqadar. The people of district enjoy all the four seasons in a year i.e. summer, winter, spring, and autumn (S. Khan et al., 2013). Annual rainfall in District varies from 400-600 mm received from two different spells of rainfall in a year; winter rainfall is due to the western disturbance, and summer rainfall is due to southwestern monsoon current. Two main rivers flowing in District i.e. Kabul and River Swat. River Kabul enter from wester side of the District and flow along the southern side of District's boundary. The Swat river is main tributary of the River Kabul and enter the District near Abazai village and flow to Kabul river in south-eastern direction till it join River Kabul (Farish et al., 2017; A. N. Khan et al., 2013).

\section{Materials and Methods}

The study utilized geospatial based methodology for flood susceptibility mapping. To analyze the hazardous area, GIS-based frequency ratio method has been used to analyze the prone area. Frequency ratio model was tested for District Charsadda, detailed and reconnaissance survey was conducted to have strong knowledge of flood conditioning factors which frequently trigger flood in study area. More the accurate conditioning factors will lead to more accurate flood susceptibility zonation.

This study is conducted to use the frequency ratio model for flood susceptibility zonation. Delineating flooded area is a most crucial part whenever dealing with flood susceptibility mapping. LANDSAT scenes are the priority of the researchers to get the information about flood. Flooded area can be extracted by classifying the water, non-water and flooded area using band 7 and band 5 of LANDSAT ETM. Foremost, the flood locations were demarcated from interpretation of moderate resolution satellite image (Landsat 7) with spatial resolution of $15 \mathrm{~m}$ pan-sharpen, total of 161 flood location were pinpoint at scale of 1:15000 with band array of 4,5,1 and 7,5,3 because flooded areas can be distinguish easily as compared to other land features; however, band combination of 3,2,1 (natural color composite) is very difficult to differentiate shallow water from soil as band combination 
of 7,5,3 can do (Mwaniki et al., 2015). However, it is necessary to validate it with the field because remote sensing technology has some errors due to the spatial resolution, clouds, and dense vegetation (Lin et al., 2006). That's why the flood locations were validated with a reconnaissance field survey along with handheld GPS. The factors contributing to flood susceptibility are: slope, elevation, aspect, curvature, profile and plan curvature, proximity to road, streams, and rivers, and land use/ land cover were selected as effective factors.

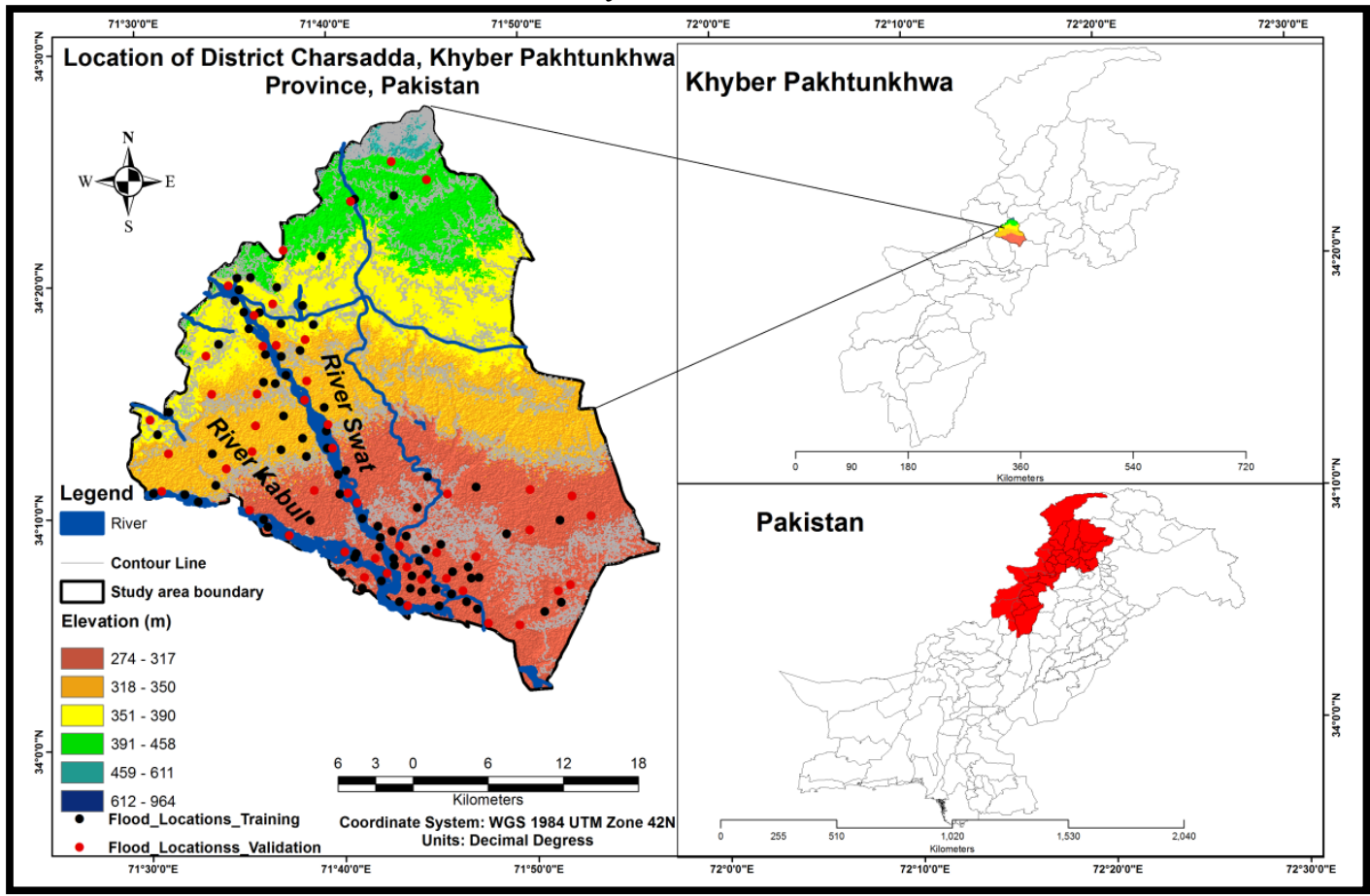

Fig. 1: Relative location of research

The data used in this study was acquired from different government line departments, community, and non-government organizations. ASTER GDEM with $30 \mathrm{~m}$ spatial resolution was downloaded from (Earth Explorer) website. DEM are the primary source to, model, analyze and display the information about topographic attributes. i.e. elevation, slope, aspect, curvature, profile and plan curvature (Forkuo, 2008; McDougall et al., 2008). DEM incorporated with GIS software can help a lot in flood analysis i.e. flood height relationship with flood affected area by using ground surface height of DEM (UMITSU et al., 2006). Curvature act as a morphology of topography. Positive curvature represent that the slope gradient is convex in upward direction; however, negative curvature indicate that the slope gradient is concave upwardly, and slope gradient will be flat if the value is zero (Ayalew and Yamagishi, 2005; Greco et al., 2007). Road network data was acquired from communication and work department Peshawar. Road cuts are anthropogenic factor that could be used for emergency response to be affected communities during floods. It's essential to have a better road network in all weathers. Road parameter get lots of attention in recent times and considered as an effective nonstructural prerequisite for flood hazard management(Sanyal and $\mathrm{Lu}, \quad 2006$ ). Administrative boundary of District Charsadda, streams, and river were extracted from toposheet 1: 50,000 acquired from survey of Pakistan (SOP). All the thematic layers and flood inventory were generated in ArcGIS 10.1 environment. 


\section{TIME SERIES PLOT OF HIGHEST RECORDED DISCHARGE OF SWAT RIVER, MUNDA HEADWORKS}

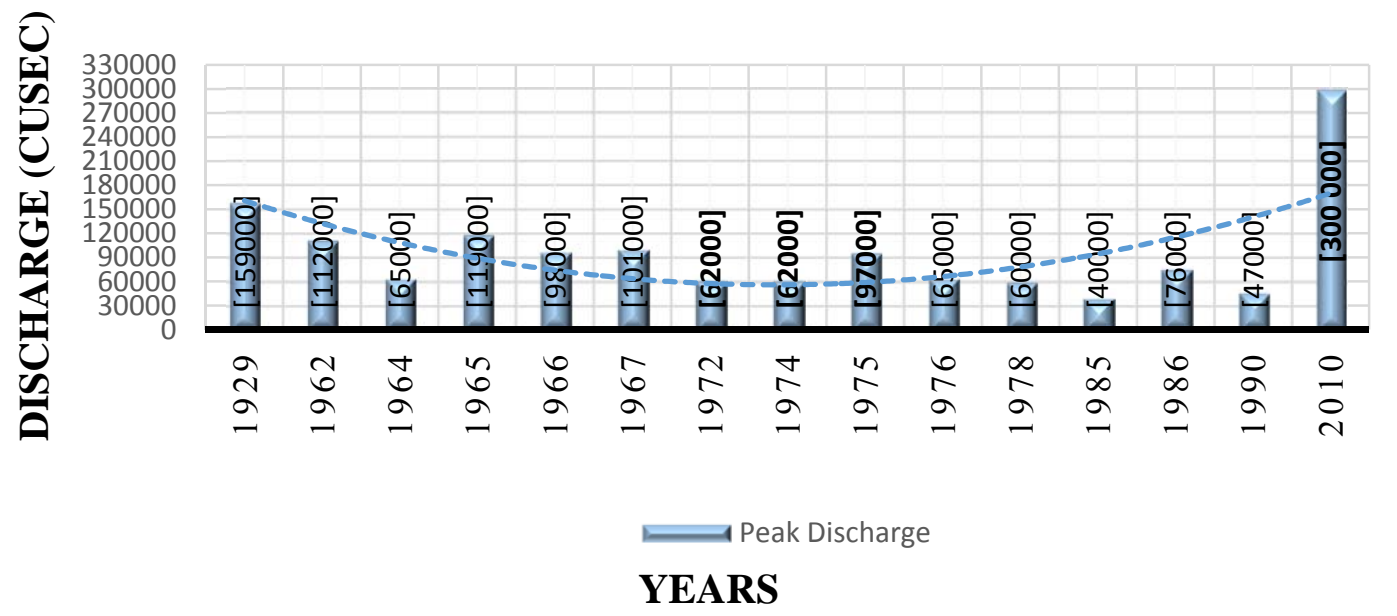

Fig 2: Highest recorded discharge of Swat river at Munda headworks 1929-2010 (Source: Provincial Irrigation and Drainage Authority, Peshawar)

It is assumed that the factors which were influencing flood in past would be same to trigger in future.

There are many reasons behind recurrent flooding in District Charsadda including heavy rainfall, climate change, human interventions in flood plain areas. Intense rainfall occur (July 27-30,2010) and due to that river channel exceed from its capacity and fail to accommodate plenty of discharge water (A. N. Khan et al., 2013). In 2010, District was worst effected due to the disastrous flood. The study area faces flood every 3 to 4 years, in 1929, 1999, 2003, 2005, 2007, and 2010 (A. N. Khan et al., 2013).

The graph above illustrates that highest discharge was recorded in 1929 and due to that flood occurs in district, there is irregular trend is shown until 1990 and a dramatic increase is shown in 2010 with a discharge of 300000 Cusec which affect the vast area with loss of lives and major damages to roads, bridges, communication system, and houses (Fig 2).

\section{Frequeny Ratio Method}

Following our assumption spatial relationship between flood locations and the parameters participating in flood susceptibility were analyzed using frequency ratio method. This method is widely used for landslide susceptibility assessment (Balamurugan et al., 2016; Intarawichian and Dasananda, 2011; S. Lee and Pradhan, 2007; Yalcin et al., 2011) and rarely found for flood susceptibility mapping (M. J. Lee et al., 2012; Rahmati et al., 2016; Tehrany et al., 2015). That's why this study is conducted, using frequency ratio method for flood susceptibility mapping. To prepare flood susceptibility map, frequency ratio method was employed using GIS techniques. It is based on connection between flood locations and its related factors to reveal the correlation between them in the study area. 


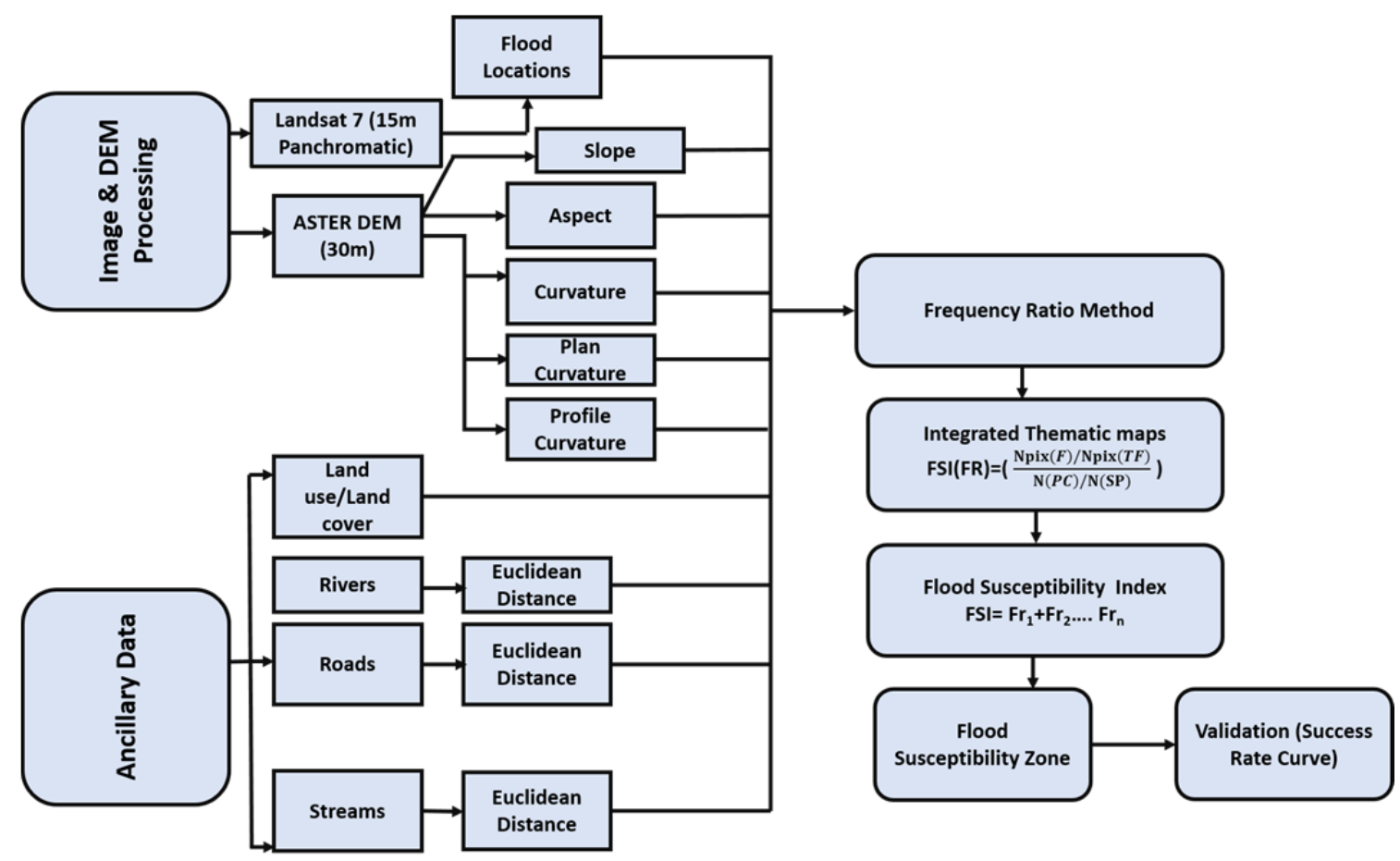

Fig 3: Methodological sequence

Frequency is calculated (Equation.1) by doing analysis of flood locations and each of sub- factor as well. Consequently, the frequency ratio of each sub-factor were calculated from their relationship with flood events as shown in (Table 1) (Akgün and Bulut, 2007; Intarawichian and Dasananda, 2011).

$$
F S I(F R)=\frac{N p i x(F) / N p i x(T F)}{N p i x(P C) / N p i x(S P)} \quad \text { Eq } 1 .
$$

Here, ' $F$ ' is the number of pixels contain flood in each parameter sub-classes, "TF" represent the total number of pixel in the study area. However, on the other side 'PC' is showing the number of pixels in each parameter sub-classes, and 'SP' presenting total number of pixels in the study area (Rahmati et al., 2016; Yalcin et al., 2011).
Where, 'FSI' is flood susceptibility index and 'FR' is frequency ratio of each factor type were summed up (Equation.2). Later on, flood susceptibility index map was normalized and divided into five zones from very low to very high susceptibility zones (Intarawichian and Dasananda, 2011; Yalcin et al., 2011).

$$
F S I=\sum F R \quad \text { Eq. } 2
$$

According to the frequency ratio method, the value of 1 is considered as an average, if the value is greater than 1 means higher correlation between flood occurrence and concerned factor and vice versa (Akgün and Bulut, 2007). 
Table 1. Spatial relationship between flooded area and its related parameters using FR method

\begin{tabular}{|c|c|c|c|c|}
\hline Factors & Classes & $\begin{array}{l}\text { Pct. Of flood } \\
\text { occurrence } \\
\text { (Npix(F)/Npix }(T F)\end{array}$ & $\begin{array}{l}\text { Pct. Of domain (sub- } \\
\text { factor) } \\
(\operatorname{Npix}(P C) / N p i x(S P)\end{array}$ & $\begin{array}{l}\text { Frequency Ratio } \\
\text { (Npix }(F) / N p i x(T F) \\
(\operatorname{Npix}(P C) / N p i x(S P)\end{array}$ \\
\hline \multirow{6}{*}{ Elevation } & $274-317$ & 59.82 & 36.67 & 1.63 \\
\hline & $318-350$ & 23.21 & 28.93 & 0.80 \\
\hline & $351-390$ & 14.28 & 19.44 & 0.73 \\
\hline & $391-458$ & 2.67 & 13.06 & 0.21 \\
\hline & $459-611$ & 0 & 1.48 & 0 \\
\hline & $612-964$ & 0 & 0.39 & 0 \\
\hline \multirow{6}{*}{ Slope } & $0-0.55^{\circ}$ & 41.07 & 40.93 & 1.00 \\
\hline & $0.56-1.39^{\circ}$ & 50.89 & 48.23 & 1.06 \\
\hline & $1.40-3.21^{\circ}$ & 8.03 & 9.32 & 0.86 \\
\hline & $3.22-6.57^{\circ}$ & 0 & 0.85 & 0 \\
\hline & $6.58-10.91^{\circ}$ & 0 & 0.45 & 0 \\
\hline & $10.92-35.68^{\circ}$ & 0 & 0.19 & 0 \\
\hline \multirow{9}{*}{ Aspect } & Flat & 13.39 & 10.32 & 1.30 \\
\hline & North & 15.17 & 10.50 & 1.45 \\
\hline & Northeast & 14.28 & 11.51 & 1.24 \\
\hline & East & 12.50 & 12.17 & 1.03 \\
\hline & Southeast & 10.71 & 13.66 & 0.78 \\
\hline & South & 15.17 & 12.88 & 1.18 \\
\hline & Southwest & 3.57 & 10.66 & 0.33 \\
\hline & West & 8.03 & 9.84 & 0.82 \\
\hline & Northwest & 7.14 & 8.42 & 0.85 \\
\hline \multirow{3}{*}{ Curvature } & Concave & 10.71 & 14.50 & 0.74 \\
\hline & Flat & 52.67 & 53.53 & 0.98 \\
\hline & Convex & 36.60 & 31.95 & 1.15 \\
\hline \multirow{3}{*}{ Profile Curvature } & Concave & 19.64 & 16.92 & 1.16 \\
\hline & Flat & 64.28 & 60.71 & 1.06 \\
\hline & Convex & 16.07 & 22.36 & 0.72 \\
\hline \multirow{3}{*}{ Plan Curvature } & Concave & 4.46 & 9.27 & 0.48 \\
\hline & Flat & 59.82 & 58.27 & 1.03 \\
\hline & Convex & 35.71 & 32.45 & 1.10 \\
\hline \multirow{6}{*}{$\begin{array}{l}\text { Land Usel Land } \\
\text { Cover }\end{array}$} & Settlement & 6.25 & 6.64 & 0.94 \\
\hline & Agriculture & 67.85 & 81.60 & 0.83 \\
\hline & Shrubs and Bushes & 1.78 & 0.98 & 1.82 \\
\hline & Rangeland & 8.03 & 3.65 & 2.20 \\
\hline & Barren Land & 2.67 & 3.58 & 0.75 \\
\hline & Waterbodies & 13.39 & 3.52 & 3.81 \\
\hline \multirow{6}{*}{ Roads } & $0-100$ & 24.10 & 46.09 & 0.52 \\
\hline & $101-200$ & 37.50 & 30.55 & 1.23 \\
\hline & $201-300$ & 14.28 & 15.24 & 0.94 \\
\hline & $301-400$ & 17.85 & 5.67 & 3.15 \\
\hline & $401-500$ & 6.25 & 1.90 & 3.29 \\
\hline & $>501$ & 0 & 0.52 & 0 \\
\hline \multirow{6}{*}{ Rivers } & $0-400$ & 66.96 & 35.44 & 1.89 \\
\hline & $401-800$ & 20.53 & 27.35 & 0.75 \\
\hline & $801-1200$ & 4.46 & 16.62 & 0.27 \\
\hline & $1201-1600$ & 5.35 & 10.38 & 0.52 \\
\hline & $1600-2000$ & 0.89 & 6.82 & 0.13 \\
\hline & $>2001$ & 1.78 & 3.35 & 0.53 \\
\hline \multirow{6}{*}{ Stream } & $0-200$ & 24.10 & 41.77 & 0.58 \\
\hline & $201-400$ & 30.35 & 31.86 & 0.95 \\
\hline & $401-600$ & 18.75 & 16.13 & 1.16 \\
\hline & $601-800$ & 10.71 & 6.47 & 1.65 \\
\hline & $801-1000$ & 10.71 & 2.56 & 4.17 \\
\hline & $>1001$ & 5.35 & 1.17 & 4.56 \\
\hline
\end{tabular}




\section{Results and Discussion}

District Charsadda has been analyzed with its ten conditioning factors to correlate them with flood inventory using frequency ratio model employed with geospatial technique. Each of the factors has been analyzed using frequency ratio method to expose the susceptibility zones. Frequency ratio method used to calculate frequency ratio (FR) values using (Equation.1) for all sub-factors in all conditioning parameters based on their relationships with flood inventory. Analysis reveal that flood is abundantly occurring on elevation of $274-317 \mathrm{~m}$ with FR value (1.63), it was observed that flood cannot happen in high altitude of the study area.

Relationship between flood inventory and slope gradient expose that $0-0.55^{\circ}$ and $0.56^{\circ}$ $1.39^{\circ}$ have the highest possibility of flood occurrence with FR value of 1.00 and 1.06 respectively and FR value decreased as the slope angle increase, it means that chances of flood decrease with an increase in slope angle. As far as slope aspect is concerned, flood is abundant on Flat (1.30), North (1.45), Northeast (1.24) and South facing slope (1.18). Convex slope of curvature, and plan curvature have the highest probability of flood occurrences with FR values 1.15 and 1.10 respectively. On the contrary, profile curvature has the highest probability of flood occurrence on concave and flat slope with FR value of 1.16 and 1.06 respectively. Among land use/land cover classes highest frequency ratio observed for the shrubs and bushes, rangeland, and water bodies 1.82, 2.20, and 3.81 respectively. Distance from river ranges 0 up to $400 \mathrm{~m}$ showed highest values of frequency ratio (1.89), analysis is evident that flood occur near the bank of river and very rare far from the river. The relationship between flood and road proximity ranges between 1.20-3.30 with distance of 100$500 \mathrm{~m}$. Relationship between streams and flood showed that there is high probability of flood occurrences with frequency ratio values $1.10-4.60$ at distance range from 400$>1000 \mathrm{~m}$.
Frequency ratio method was implemented for flood susceptibility index (FSI) from which flood susceptibility map was prepared. All the conditioning factors were converted into raster format with $30 \times 30 \mathrm{~m}$ grid size and their frequency ratio values were calculated using (Equation.1). Summation of all the frequency ratio values were taken using (Equation.2) and eventually, got the flood susceptibility index, higher FSI values shows the higher probability to flood and vice versa. To evaluate the impact of each factor in final susceptibility index; the statistical relationship shown in (Table 1). The flood susceptibility map (Fig. 6 ) produced by using ten conditioning parameters and were divided into five susceptibility zones with natural break classification method i.e. very low (19.09\%), low (20.54\%), moderate (19.91\%), high (34.99\%) and very high (5.45\%).

(Rahmati et al., 2016) reveal that bivariate statistical tools are useful for flood susceptibility assessment and flood mitigation. The main advantage of frequency ratio method is conceiving the impact of subfactors of every conditioning parameter (Tehrany et al., 2014); though, the drawback of frequency ratio method that it ignore the relationship among independent variables (M. J. Lee et al., 2012). (Rahmati et al., 2016) applied frequency ratio method and weight of evidence for flood susceptibility assessment in Golastan province of Iran.

Results revealed that FR method has high forecasting accuracy as compared to weight of evidence. (M. J. Lee et al., 2012) used frequency ratio method for flood susceptibility assessment in Busan, South Korea and prediction accuracy found 91.5\%. However, (Balamurugan et al., 2016) used frequency ratio and fuzzy gamma operator model for landslide susceptibility assessment for Manipur, India and their results showed that the area under curve for frequency ratio and fuzzy gamma model was $80.56 \%$ and $91.5 \%$ respectively. 


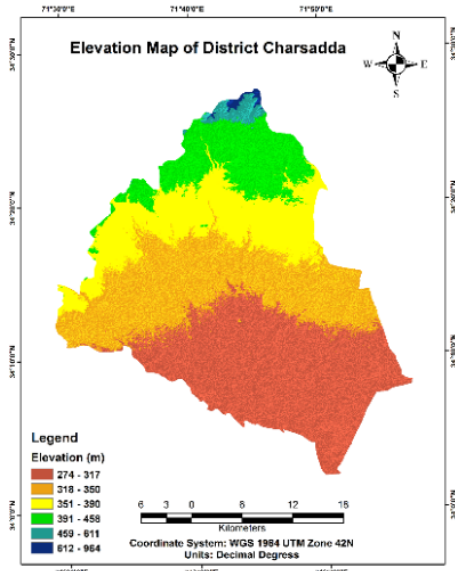

(a)

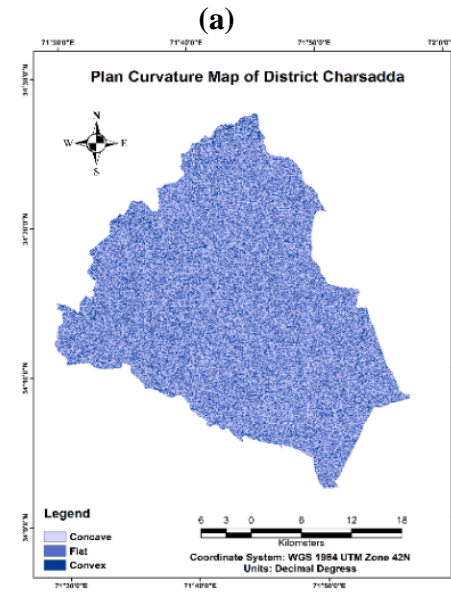

(e)

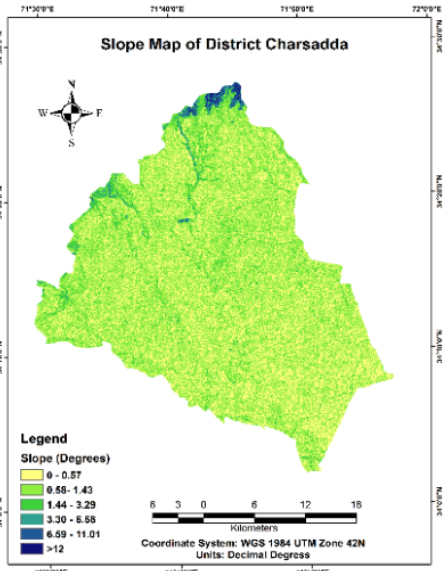

(b)

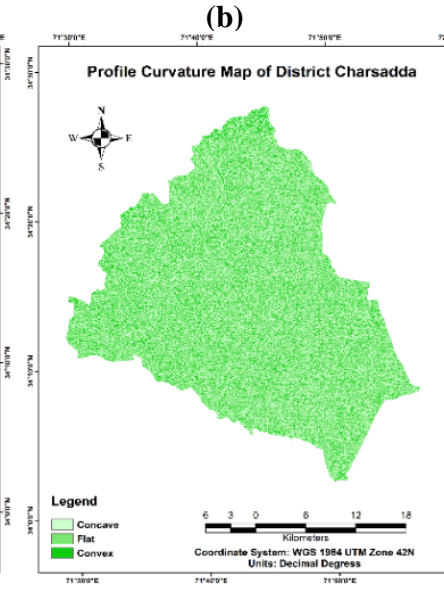

(f)

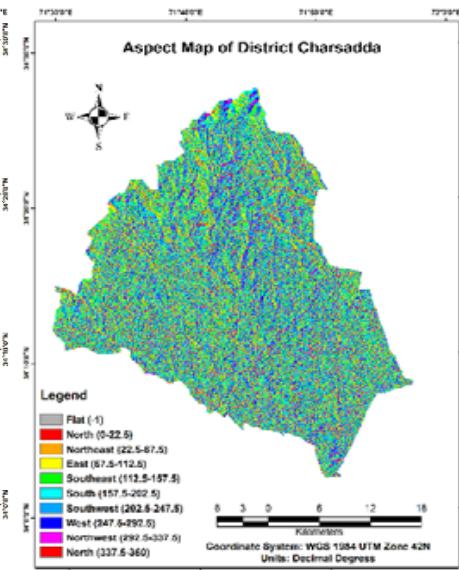

(c)

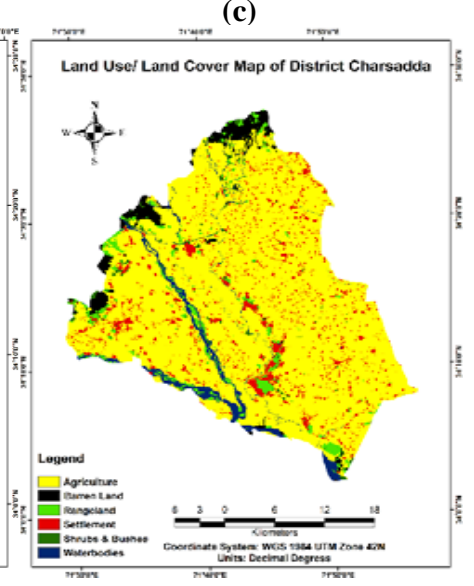

(g)

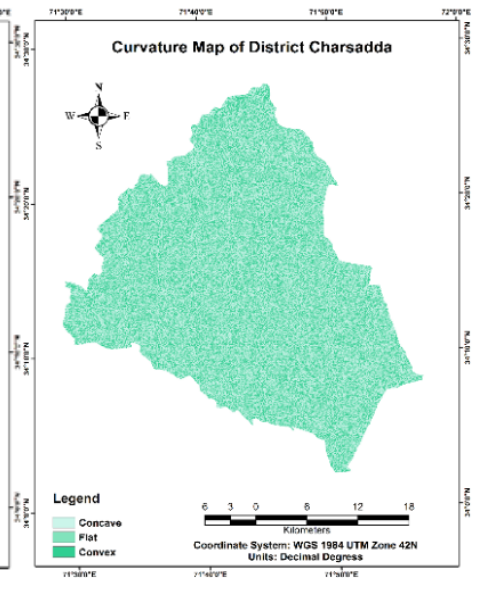

(d)

Fig 4: (a) Elevation, (b) Slope, (c) Aspect, (d) Curvature, (e) Plan curvature, (f) Profile curvature, (g) LULC, 


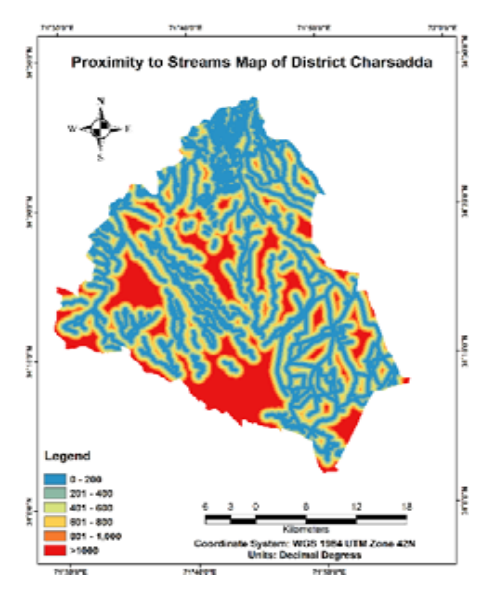

(h)

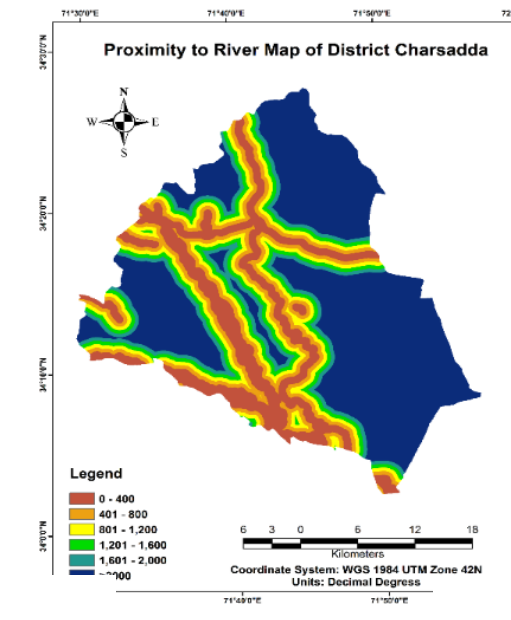

(i)

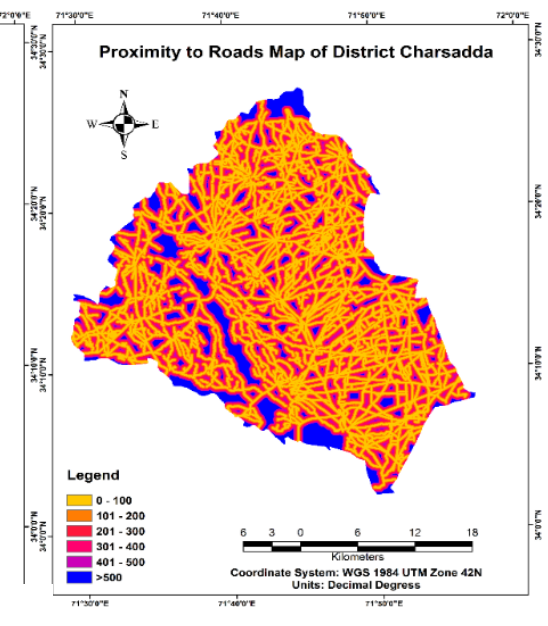

(j)

Fig 4 cont. (h) Proximity to streams, (i) Proximity to roads, (j) Proximity to rivers 


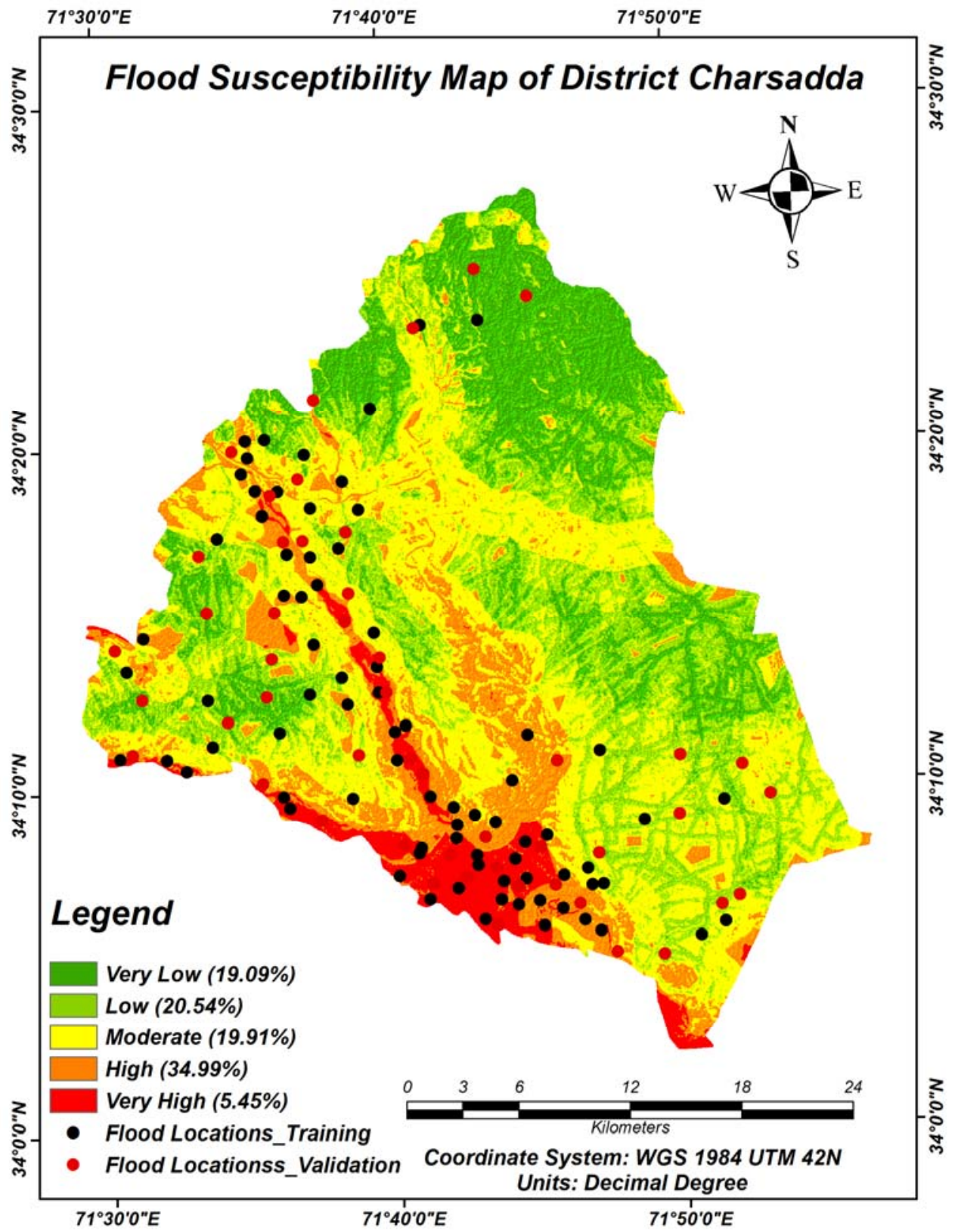

Fig. 5: Flood susceptibility map using frequency ratio method

\section{Validation using area under curve method}

Validation of the model should be examined to show how well the model performed because it does not matter which method has been used, it is very important to verify the results (Chung and Fabbri, 2003).

For prediction accuracy, the model was validated by comparing the flood hazard map with flood data (Validation flood locations). Results were examined using success rate curve method (Pourghasemi et al., 2012; Rahman et al., 2017). From total 161 flood locations 70\% (112) were used for analysis of the model and 30\% (49) were used in validation of the model. Success rate curve was calculated for accuracy assessment. FSI values were divided into 100 equal classes and sorted in descending order with high to 
low susceptible. The flood validation dataset overlaid on it and the area under effected flood locations falls in susceptible class was calculated using zonal statistics tool in ArcGIS. Eventually, cumulative percentage was calculated and success rate curve was plotted. Final flood hazard map was validated using success rate curve and the area under curve was found $92.26 \%$. area under curve validated the satisfactory results for flood susceptibility (Rahman et al., 2017).

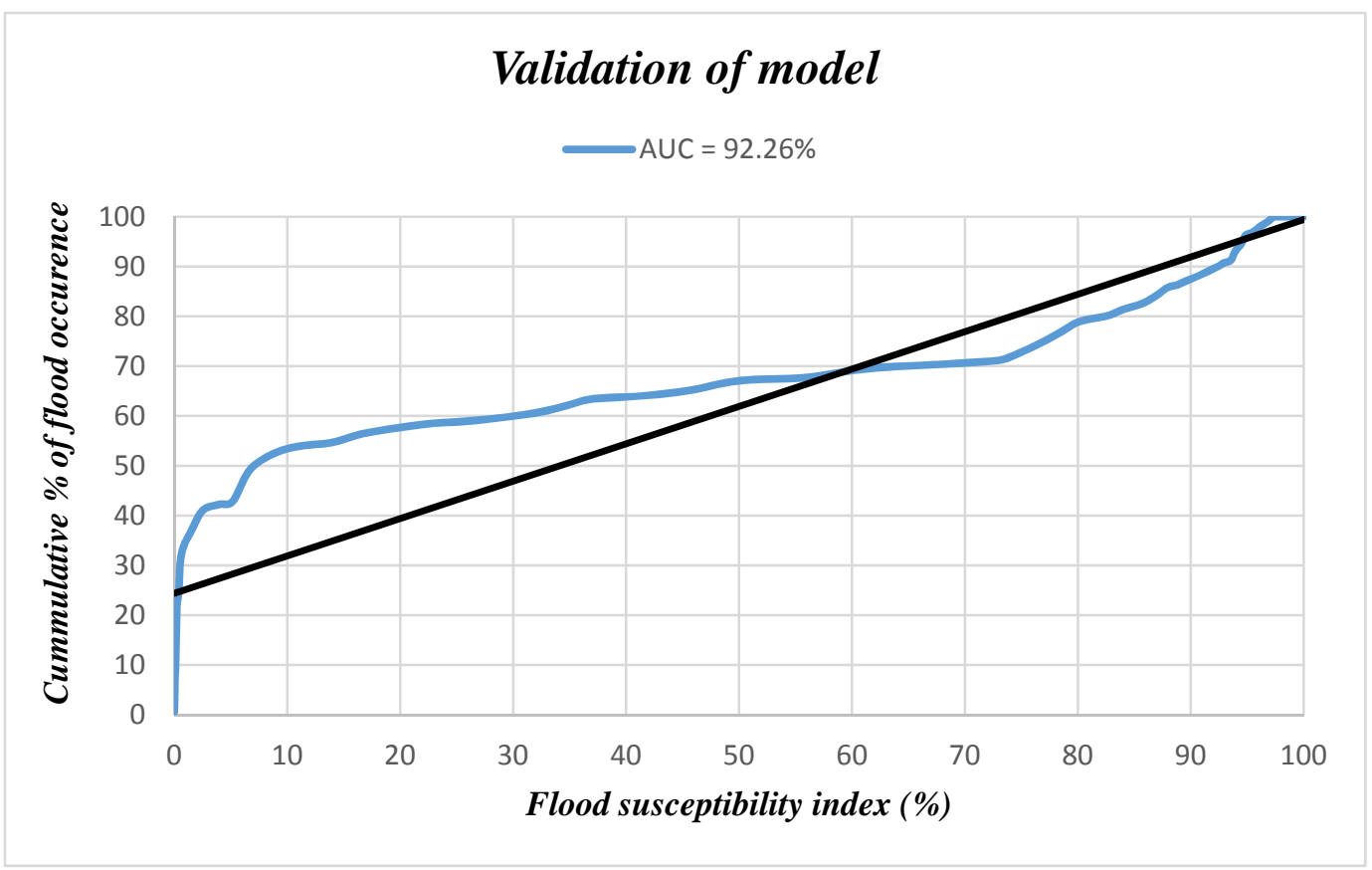

Fig 7: Validation of flood susceptibility

\section{Conclusion}

Flood hazard is the destructive and frequently occurring phenomena in the study area and cause heavy damages to human lives and economy. Frequency ratio method is very quick and easy to apply. Frequency ratio method employed with geospatial techniques is used for its reliability towards flood susceptibility assessment and results with accuracy of $92.26 \%$ reveal that method is reliable and can be used for flood susceptibility assessment. This study used 30m ASTER DEM along with ancillary data i.e. land use/land cover, hydrological data (Rivers, stream) and anthropogenic data (roads) for flood susceptibility mapping. Furthermore, it proposes that statistical techniques employed with geospatial techniques can effectively assess flood susceptibility. The drastic 2010 flood in
Charsadda trigger due to heavy monsoon rainfall. Dramatically, geospatial technology is in the market due to its vast applicable areas i.e. disaster management, agriculture monitoring, damage assessment, spatial planning, and urban planning. According to this research, it exposed that there is very high flood susceptibility zone around the banks of river and around stream on the western and south-western side of study. Flood is the natural process that cannot be completely ended but damages can be minimizing by proper management and planning.

Frequency ratio method can show us more authentic results by using high resolution satellite image and to demarcate more flood effected areas. There should be more meteorological stations in the study area for reporting, measuring rainfall, discharge data, and flood forecasting. Spatial data should be made and easily available to all. These maps 
are useful for land use planning and mitigation strategies for future to reduce the damages. These maps can prove their usefulness for planners and engineers in terms of implementation of necessary actions for developments by considering the highly susceptible areas. By field visits it was observed that people built their houses in flood prone areas. Indeed, it is suggested that houses should be built in safer places and housing structures (mud to concrete) should also be change and properly assist by engineers and planers that can reduce the vulnerability of community towards flood susceptibility. Flood forecasting and warning centers should be installed in the study area.

\section{Acknowledgements}

The primary author is thankful to Naresuan University International Student Scholarship for funding the author's master's degree. Author is thankful to provincial irrigation and drainage authority, and Pakistan meteorological department, Peshawar for providing discharge data.

\section{Authors Contribution}

Muhammad Farhan Ul Moazzam and Anujit Vansarochana designed the study. Muhammad Farhan Ul Moazzam collected all the data from field, analyze the results and made all the maps and graphs, and wrote the manuscript under guidance of Anujit Vansarochana. AttaUr-Rahman reviewed the manuscript many times and gave scientific suggestion for the improvement of article. Furthermore, proof reading of the manuscript was done by Miss Tamkeen Urooj Paracha.

\section{Conflict of Interest}

Authors declare there is no conflict of interest. The funding sponsor (Naresuan University International Student Scholarship) had no part in planning of this study, collecting data, analysis, or to interpret the data. Writing the manuscript and to publish the results are solely authors decision and contribution.

\section{References}

Adeoye, N., Ayanlade, A., and Babatimehin, O. (2009). Climate change and menace of floods in Nigerian cities: socio-economic implications. Advances in Natural and Applied Sciences, 3(3), 369-378.

Ahmad, H., Bokhari, J., and Siddiqui, Q. (2011). Flashflood risk assessment in Pakistan. Paper presented at the $71 \mathrm{st}$ Annual Session Proceedings. Pakistan Engineering Congress, Pakistan.

Akgün, A., and Bulut, F. (2007). GIS-based landslide susceptibility for Arsin-Yomra (Trabzon, North Turkey) region. Environmental Geology, 51(8), 13771387. doi:10.1007/s00254-006-0435-6

Algan O, Gazioğlu C, Çağatay N, Yücel ZY, Gönençgil B. (1999). Sediment and water influxes into the Black Sea by Anatolian rivers. Zeitschrift für Geomorphologie 43: 61-79.

Atta-ur-Rahman, and Khan, A. N. (2013). Analysis of 2010-flood causes, nature and magnitude in the Khyber Pakhtunkhwa, Pakistan. Natural Hazards, 66(2), 887904. doi:10.1007/s11069-012-0528-3

Ayalew, L., and Yamagishi, H. (2005). The application of GIS-based logistic regression for landslide susceptibility mapping in the Kakuda-Yahiko Mountains, Central Japan. Geomorphology, 65(1-2), 15-31. doi:http://dx.doi.org/10.1016/j.geomorph. 2004.06.010

Azaz, L. K. (2010). Using remote sensing and GIS for damage assessment after flooding, the case of Muscat, Oman after Gonu tropical cyclone 2007: Urban planning perspective: na.

Balamurugan, G., Ramesh, V., and Touthang, M. (2016). Landslide susceptibility zonation mapping using frequency ratio and fuzzy gamma operator models in part of NH-39, Manipur, India. Natural Hazards, $\quad 84(1)$, 465-488. doi:10.1007/s11069-016-2434-6

Brivio, P. A., Colombo, R., Maggi, M., and Tomasoni, R. (2002). Integration of remote sensing data and GIS for accurate mapping of flooded areas. International Journal of Remote Sensing, 23(3), 429441. doi:10.1080/01431160010014729 
Chung, C.-J. F., and Fabbri, A. G. (2003). Validation of Spatial Prediction Models for Landslide Hazard Mapping. Natural Hazards, 30(3), 451-472. doi:10.1023/B:NHAZ.0000007172.62651 $.2 b$

Dilley, M. (2005). Natural disaster hotspots: a global risk analysis (Vol. 5): World Bank Publications.

District wise census report. (2017).Retrieved from

http://www.pbscensus.gov.pk/sites/defaul t/files/DISTRICT WISE CENSUS RES ULTS CENSUS $2017 . \bar{d} \mathrm{df}$

Duan, M., Zhang, J., Liu, Z., and Aekakkararungroj, A. (2009). Use of remote sensing and GIS for flood hazard mapping in Chiang Mai Province, northern Thailand. Paper presented at the International Conference on Geospatial Solutions for Emergency Management and the 50th Anniversary of the Chinese Academy of Surveying and Mapping, Beijing, China.

Farish, S., Munawar, S., Siddiqua, A., Alam, N., and Alam, M. (2017). Flood Risk Zonation Using GIS Techniques: District Charsadda, 2010 Floods Pakistan. Environmental Risk Assessment and Remediation, 1(2).

Forkuo, E. K. (2008). Digital terrain modeling in a GIS environment.

Greco, R., Sorriso-Valvo, M., and Catalano, E. (2007). Logistic Regression analysis in the evaluation of mass movements susceptibility: The Aspromonte case study, Calabria, Italy. Engineering Geology, $\quad 89(1), \quad 47-66$. doi:https://doi.org/10.1016/j.enggeo.2006. 09.006

Intarawichian, N., and Dasananda, S. (2011). Frequency ratio model based landslide susceptibility mapping in lower Mae Chaem watershed, Northern Thailand. Environmental Earth Sciences, 64(8), 2271-2285. doi:10.1007/s12665-011$1055-3$

Kaya, H., and Gazioğlu, C. (2015). Real estate development at landslides. International Journal of Environment and Geoinformatics, 2(1), 62-71.

Khan, A. N., Khan, B., Qasim, S., and Khan, S. N. (2013). Causes, Effects and
Remedies: A Case Study of Rural Flooding in District Charsadda, Pakistan. Journal of Managerial Sciences, 7(1).

Khan, S., Shahnaz, M., Jehan, N., Rehman, S., Shah, M. T., and Din, I. (2013). Drinking water quality and human health risk in Charsadda district, Pakistan. Journal of Cleaner Production, 60, 93101.

doi:https://doi.org/10.1016/j.jclepro.2012. 02.016

Lee, M. J., Kang, J. e., and Jeon, S. (2012, 22-27 July 2012). Application of frequency ratio model and validation for predictive flooded area susceptibility mapping using GIS. Paper presented at the 2012 IEEE International Geoscience and Remote Sensing Symposium.

Lee, S., and Pradhan, B. (2007). Landslide hazard mapping at Selangor, Malaysia using frequency ratio and logistic regression models. Landslides, 4(1), 3341. doi:10.1007/s10346-006-0047-y

Lin, C.-W., Liu, S.-H., Lee, S.-Y., and Liu, C.-C. (2006). Impacts of the Chi-Chi earthquake on subsequent rainfallinduced landslides in central Taiwan. Engineering Geology, 86(2), 87-101. doi:https://doi.org/10.1016/j.enggeo.2006. 02.010

McDougall, K., Liu, X., Basnet, B. B., and Apan, A. (2008). Evaluation of current DEM accuracy for Condamine Catchment.

Mwaniki, M. W., Moeller, M. S., and Schellmann, G. (2015). A comparison of Landsat 8 (OLI) and Landsat 7 (ETM+) in mapping geology and visualising lineaments: A case study of central region Kenya. The International Archives of the Photogrammetry, Remote Sensing and Spatial Information Sciences, Volume XL-7/W3, 7. doi:10.5194

Pourghasemi, H. R., Pradhan, B., and Gokceoglu, C. (2012). Application of fuzzy logic and analytical hierarchy process (AHP) to landslide susceptibility mapping at Haraz watershed, Iran. Natural Hazards, 63(2), 965-996. doi:10.1007/s1 1069-012-0217-2

Rahman, G., Rahman, A.-U., and Collins, A. (2017). Geospatial analysis of landslide susceptibility and zonation in shahpur 
valley, eastern hindu kush using frequency ratio model. Proceedings of the Pakistan Academy of Sciences, 54(3), 149-163.

Rahmati, O., Pourghasemi, H. R., and Zeinivand, H. (2016). Flood susceptibility mapping using frequency ratio and weights-of-evidence models in the Golastan Province, Iran. Geocarto International, 31(1), 42-70. doi:10.1080/10106049.2015.1041559

Sanyal, J., and Lu, X. X. (2006). GIS based flood hazard mapping at different administrative scales: A case study in Gangetic West Bengal, India. Singapore Journal of Tropical Geography, 27(2), 207-220.

Tehrany, M. S., Lee, M.-J., Pradhan, B., Jebur, M. N., and Lee, S. (2014). Flood susceptibility mapping using integrated bivariate and multivariate statistical models. Environmental Earth Sciences, 72(10), 4001-4015. doi:10.1007/s12665014-3289-3

Tehrany, M. S., Pradhan, B., and Jebur, M. N. (2015). Flood susceptibility analysis and its verification using a novel ensemble support vector machine and frequency ratio method. Stochastic Environmental Research and Risk Assessment, 29(4), 1149-1165. doi:10.1007/s00477-015-1021-9

Uddin, K., and Shrestha, B. (2011). Assessing flood and flood damage using Remote Sensing: a case study from Sunsari, Nepal. Paper presented at the 4th International Conference on Water and Flood Management.

Uddin, K., Gurung, D. R., Giriraj, A., and Shrestha, B. (2013). Application of remote sensing and GIS for flood hazard management: a case study from Sindh Province, Pakistan. American Journal of Geographic Information System, 2(1), 15.

UMITSU, M., HIRAMATSU, T., and TANAVUD, C. (2006). Research on the flood and micro landforms of the Hat Yai Plain, Southern Thailand with SRTM Data and GIS. Transactions, Japanese Geomorphological Union, 27(2), 205219.
UNDP, H. (2004). Reducing Disaster Risk: A Challenge for Development-A Global Report. New York, USA: UNDP.

Yalçın, A., Reis, S., Aydinoglu, A. C., and Yomralığlu, T. (2011). A GIS-based comparative study of frequency ratio, analytical hierarchy process, bivariate statistics and logistics regression methods for landslide susceptibility mapping in Trabzon, NE Turkey. CATENA, 85(3), 274-287.

doi:http://dx.doi.org/10.1016/j.catena.201 1.01 .014 